\title{
PENGARUH KUALITAS PRODUK DAN HARGA TERHADAP PEMBELIAN KEMBALI PRODUK GOSH DI KOTA PALU DENGAN KEPERCAYAAN MEREK SEBAGAI VARIABEL ANTARA (Studi Pada Mahasiswa Universitas Tadulako)
}

\author{
HUTHAMY MARENDA PUTRI \\ JOHNNY TANAMAL \\ PONIRIN \\ Jurusan Manajemen, Fakultas Ekonomi, Universitas Tadulako \\ Email: huthamy.putri@yahoo.com
}

\begin{abstract}
This study aims to determine the effect of product quality and price on the repurchase of GOSH products in Palu City with brand trust as a variable between. Exogenous variables used in this research are Product Quality (X1) and Price (X2), while endogenous variable is Brand Trust (Y) and Repurchase (Z). This type of research is quantitative. The method of this research is descriptive causal. The samples used in this study were as many as 96 respondents with the form of sampling using the technique of Purposive Sampling. Data analysis method used in this research is the method of analysis PLS (Partial Least Square). The results of this study indicate that the price has a significant effect on brand trust (t-statistics 2,66), but the price has no significant effect on repurchase (t-statistic value 1,74). While brand trust has significant effect on repurchase (t-statistic value 7,71), likewise with product quality significantly influence brand trust (t-statistic value 4,71), but product quality has no significant effect on repurchase (value t-statistics 0.93 ).
\end{abstract}

Keywords: Product Quality, Price, Brand Trust, Repurchase.

Penelitian ini bertujuan untuk mengetahui pengaruh kualitas produk dan harga terhadap pembelian kembali produk GOSH di Kota Palu dengan kepercayaan merek sebagai variabel antara. Variabel eksogen yang digunakan dalam penelitian ini adalah Kualitas Produk (X1) dan Harga (X2), Sedangkan variabel endogen adalah Kepercayaan Merek (Y) dan Pembelian Kembali (Z). Jenis penelitian ini adalah kuantitatif. Metode penelitian ini adalah deskriptif kausal. Sampel yang digunakan pada penelitian ini yaitu sebanyak 96 responden dengan bentuk pengambilan sampel menggunakan teknik Purposive Sampling. Metode analisis data yang digunakan dalam penelitian ini adalah metode analisis PLS (Partial Least Square). Hasil penelitian ini menunjukkan bahwa harga berpengaruh signifikan terhadap kepercayaan merek (nilai t-statistik 2,66), namun harga tidak berpengaruh signifikan terhadap pembelian kembali (nilai t-statistik 1,74). Sementara kepercayaan merek berpengaruh signifikan terhadap pembelian kembali (nilai t-statistik 7,71), demikian juga dengan kualitas produk berpengaruh signifikan terhadap kepercayaan merek (nilai t-statistik 4,71), akan tetapi kualitas produk tidak berpengaruh signifikan terhadap pembelian kembali (nilai t-statistik 0,93).

Kata kunci: Kualitas Produk, Harga, Kepercayaan Merek, Pembelian Kembali.

\section{PENDAHULUAN}

GOSH adalah salah satu outlet yang berusaha menjawab kebutuhan dan keinginan masyarakat dengan membuka gerai di Kota Palu. Gerai tersebut berlokasi di Jalan Cumi-cumi (Taman Ria) Palu Grand Mall. Berbagai macam produk ditawarkan di outlet ini, seperti tas, sepatu, sandal, serta aksesoris-aksesoris lainnya yang sedang digemari masyarakat.

Mc \& Perrefault (2003) mengemukakan bahwa, "Produk merupakan hasil dari produksi yang akan dilempar kepada konsumen untuk didsistribusikan dan dimanfaatkan konsumen untuk memenuhi kebutuhannya". Kualitas didefinisikan sebagai keseluruhan ciri serta sifat barang dan jasa yang berpengaruh pada kemampuan memenuhi kebutuhan yang dinyatakan maupun yang tersirat (Kotler dalam Rendy, 2015). Harga akan cenderung menjelaskan kualitas produk barang tersebut. Kotler dan 
Putri, H.M.

Amstrong (2001) menyatakan bahwa: "Jumlah uang yang dibebankan untuk sebuah produk atau jasa". Lebih luas lagi, harga adalah jumlah nilai yang konsumen pertukarkan untuk mendapatkan manfaat dari memiliki atau menggunakan produk atau jasa". Edris (2013) menyatakan kepercayaan merek adalah kepercayaan konsumen bahwa merek yang mereka inginkan dapat diandalkan, memberikan jaminan tidak merugikan dan kinerjanya sangat berharga atau sangat bermanfaat.

Hasil observasi dan wawancara dengan mahasiswa yang menjadi konsumen produk GOSH yang berinisial DS mengatakan bahwa belakangan ini produk GOSH sudah tidak menarik dan berbeda dengan sebelumnya namun harganya masih tetap sama dengan harga sebelumnya sehingga produk GOSH sudah jarang disukai oleh masyarakat khususnya dalam kalangan mahasiswa fakultas ekonomi Universitas Tadulako. Mahasiswa yang lainnya lagi yang berinisial FAM mengatakan bahwa kualitas yang dimiliki oleh produk GOSH mempunyai daya tahan yang kurang kuat contohnya seperti tas merek GOSH yang memiliki warna cepat pudar sehingga mahasiswa mengeluh akan hal tersebut. Penelitian ini bertujuan untuk mengetahui dan menganalisa: pengaruh kualitas produk terhadap kepercayaan merek GOSH di Kota Palu, pengaruh kualitas produk terhadap pembelian kembali produk GOSH di Kota Palu, pengaruh harga terhadap kepercayaan merek GOSH di Kota Palu, pengaruh harga terhadap pembelian kembali produk $G O S H$ di Kota Palu, dan pengaruh kepercayaan merek terhadap pembelian kembali produk GOSH di Kota Palu.

\section{KAJIAN LITERATURE}

\section{Pengertian Kualitas Produk}

Kotler \& Amstrong (2012) mendefinisikan produk sebagai sesuatu yang dapat ditawarkan ke pasar untuk mendapatkan perhatian, akuisisi, penggunaan, atau konsumsi yang mungkin memuaskan keinginan atau kebutuhan. Tjiptono (2008) menyatakan bahwa kualitas merupakan perpaduan antara sifat dan karakteristik yang menentukan sejauh mana keluaran dapat memenuhi prasyarat kebutuhan pelanggan atau menilai sampai seberapa jauh sifat dan karakteristik itu memenuhi kebutuhannya. Kualitas produk adalah "The ability of a product to perform its functions, it includes the product's overall durability, reliability, precision, ease of operation and repair, and other valued attributes" yang artinya kemampuan sebuah produk dalam memperagakan fungsinya, hal itu termasuk keseluruhan durabilitas, reliabilitas, ketetapan, kemudahan mengoperasikan dan reparasi produk juga atribut produk lainnya (Kotler dan Amstrong dalam Rendy, 2015).

\section{Dimensi Kualitas Produk}

Menurut Tjiptono dalam Rendy, (2015) kualitas mencerminkan semua dimensi penawaran produk yang menghasilkan manfaat (benefits) dari pelanggan. Dimensi kualitas produk adalah:

1. Performance (Kinerja)

Berhubungan dengan karakteristik operasi dasar dari sebuah produk.

2. Durability (Daya Tahan)

Yang berati berapa lama atau umur produk yang bersangkutan bertahan sebelum produk tersebut harus diganti. Semakin besar frekuensi pemakaian konsumen terhadap peroduk maka semakin besar pula daya produk.

3. Conformance to Specifications (Kesesuaian dengan Spesifikasi)

Sejauh mana karakteristik operasi dasar dari sebuah produk memenuhi spesifikasi tertentu dari konsumen atau tidak ditemukannya cacat pada produk.

4. Features (Fitur)

Karakteristik produk yang dirancang untuk menyempurnakan fungsi produk atau menambah ketertarikan konsumen terhadap produk.

5. Reliability (Reliabilitas)

Probabilitas bahwa produk akan bekerja dengan memuaskan atau tidak dalam periode waktu tertentu. Semakin kecil kemungkinan terjadinya kerusakan maka produk tersebut dapat diandalkan.

6. Aesthetic (Estetika) 
Berhubungan dengan bagaimana penampilan produk.

7. Perceived Quality (Kesan Kualitas)

Sering dibilang merupakan hasil dari penggunaan pengukuran yang dilakukan secara tidak langsung karena terdapat kemungkinan bahwa konsumen tidak mengerti atau kekurangan informasi atas produk yang bersangkutan.

8. Serviceability (Kemampuan Melayani)

Meliputi kecepatan dan kemudahan untuk direparasi, serta kompetensi dan keramahtamaan staf layanan.

\section{Pengertian Harga}

Harga merupakan salah satu bagian dari bauran pemasaran (marketing mix) yang penting dalam pemasaran produk. Menurut Prawira, Bayu, \& Yasa Kerti (2014). Menurut Ghanimata \& Kamal (2012) Harga adalah jumlah uang yang ditagihkan atas suatu produk atau jasa. Lebih luas lagi, harga adalah jumlah semua nilai yang diberikan oleh pelanggan untuk mendapatkan keuntungan dari memiliki atau menggunakan suatu produk atau jasa.

Swastha (2006) mendefinsikan harga sebagai jumlah uang (ditambah beberapa barang kalau mungkin) yang dibutuhkan untuk menetapkan sejumlah kombinasi dari barang beserta pelayanannya. Menurut Purwati, Setiawan, \& Rohmawati (2012). Selain dari kualitas produk, pengaruh harga suatu produk juga sangat penting. Jika harga rendah maka permintaan produk yang ditawarkan meningkat dan jika harga produk semakin tinggi maka permintaan produk semakin rendah. Harga memiliki peran utama dalam proses pengambilan keputusan para pembeli Ghanimata \& Kamal, (2012) yaitu:

1. Peranan alokasi harga, yaitu fungsi harga dalam membantu para pembeli untuk memutuskan cara memperoleh manfaat dan utilitas tertinggi yang diharapkan berdasarkan daya belinya.

2. Peranan informasi dari harga, yaitu fungsi harga dalam membidik konsumen mengenai faktorfaktor produk, seperti kualitas. Hal ini terutama bermanfaat dalam situasi dimana pembeli mengalami kesulitan untuk menilai faktor produk atau manfaatnya secara objektif. Persepsi yang sering muncul adalah bahwa harga yang mahal mencerminkan kualitas yang tinggi sehingga konsumen menilai harga yang ditetapkan sesuai dengan kualitas produk maupun jasa yang ditetapkan.

Menurut Tjiptono, Chandra, \& Adriana, (2008) Harga memainkan peranan penting bagi perekonomian secara makro, konsumen, dan perusahaan yaitu:

1. Bagi Perekonomian

Harga produk memengaruhi tingkat upah, sewa, bunga, dan laba. Harga merupakan legulator dasar dalam sistem perekonomian, karena harga berpengaruh terhadap alokasi faktor-faktor produksi seperti tenaga kerja, tanah, modal, dan kewirausahaan. Sebagai alokator sumber daya, harga menentukan apa yang akan diproduksi (penawaran) dan siapa yang akan membeli barang dan jasa yang dihasilkan (permintaan).

2. Bagi Konsumen

Penjualan ritel, ada segmen pembeli yang sangat sensitive terhadap faktor harga (menjadikan harga sebagai satu-satunya pertimbangan membeli produk) dan ada pula yang tidak. Mayoritas konsumen agak sensitive terhadap harga, namun juga mempertimbangkan faktor lain (seperti citra merek, lokasi toko, layanan, nilai (value), dan kualitas). Selain itu, persepsi konsumen terhadap kualitas produk sering kali dipengaruhi oleh harga, dalam beberapa kasus, harga yang mahal dianggap mencerminkan kualitas tinggi, terutama dalam kategori specialty products.

3. Bagi perusahaan

Dibandingkan dengan bauran pemasaran lainnya (produk, distribusi, dan promosi) yang membutuhkan pengeluaran dana dalam jumlah besar, harga merupakan satu-satunya elemen bauran 
Putri, H.M.

pemasaran yang mendatangkan pendapatan. Singkat kata, perusahaan mendapatkan uang melalui harga yang dibebankan atau produk atau jasa yang dijualnya.

\section{Pengertian Kepercayaan Merek}

Menurut UU Merek No. 15 tahun 2001 pasal 1 ayat 1, "Merek adalah tanda yang berupa gambar, nama, kata, huruf, angka-angka, susunan warna, atau kombinasi dari unsur-unsur tersebut yang memiliki daya pembeda dan digunakan dalam kegiatan perdagangan barang atau jasa". Menurut American Marketing Association, merek adalah nama, istilah, tanda, simbol, rancangan, atau kombinasi dari hal-hal tersebut, yang dimaksudkan untuk mengidentifikasi barang atau jasa dari seorang atau kelompok penjual dan untuk membedakannya dari produk pesaing. Kotler \& Keller (2006).

Menurut Surachman (2008) pengertian merek terbagi dalam enam tingkatan yaitu:

1. Merek sebagai atribut; merek mengingatkan pada atribut-atribut tertentu.

2. Merek sebagai manfaat; yaitu suatu merek lebih dari serangkaian atribut, pelanggan tidak membeli atribut, tetapi mereka membeli manfaat.

3. Merek sebagai nilai, yaitu merek menyatakan sesuatu tentang nilai produk, nilai produsen atau pemegang merek dan nilai pelanggan.

4. Merek sebagai budaya; merek berperan mewakili budaya tertentu.

5. Merek sebagai kepribadian; merek mencerminkan kepribadian tertentu.

6. Merek sebagai pemakai; merek dapat menunjukkan jenis konsumen yang membeli atau menggunakan produk tersebut.

Kepercayaan pada merek (brand trust) didefinisikan sebagai keinginan pelanggan untuk bersandar pada sebuah merek dengan risiko-risiko yang dihadapi karena ekspektasi terhadap merek itu akan menyebabkan hasil yang positif (Lau \& Lee (1999). Kepercayaan terbangun karena adanya harapan bahwa pihak lain akan bertindak sesuai dengan kebutuhan dan keinginan konsumen.

Menurut Kustini, Nuruni, \& Ika, (2011) brand trust dapat diukur melalui dimensi viabilitas (dimension of viability) dan dimensi intensionalitas (dimension of intentionality).

1. Dimension of Viability

Dimensi ini mewakili sebuah persepsi bahwa suatu merek dapat memenuhi dan memuaskan kebutuhan dan nilai konsumen. Dimensi ini dapat diukur melalui indikator kepuasan dan nilai (value).

\section{Dimension of Intentionality}

Dimensi ini mencerminkan perasaan aman dari seorang individu terhadap suatu merek. Dimensi ini dapat diukur melalui indikator security dan trust.

\section{Pengertian Pembelian Kembali}

Menurut Andre (2009) pembelian ulang merupakan keinginan konsumen untuk menggunakan kembali produk yang sama dimasa yang akan datang. Sedangkan menurut Hawkins, Mothersbaugh dan Best dalam Geofanny dan Chairy (2010) pembelian kembali sebagai suatu kegiatan membeli kembali yang dilakukan oleh konsumen terhadap suatu produk dengan merek yang sama tanpa diikuti oleh perasaan yang berarti terhadap produk tersebut.

Konsumen cenderung melakukan pembelian kembali untuk produk-produk ternama atau produk dengan merek yang telah dikenal luas terlepas dari apakah produk tersebut berharga mahal atau murah dan apakah produk high involevement atau low involvement. Akhir dan Othman dalam Geofanny dan Chairy (2010). Menurut Cleland dan Bruno dalam Simamora (2003), menyatakan bahwa yang dipertimbangkan konsumen dalam melakukan pembelian ulang hanya ada dua bagian yaitu: faktor harga dan bukan harga. Faktor bukan harga terdiri dari faktor produk dan non produk. Faktor produk adalah atribut-atribut yang terkait langsung dengan produk. Sedangkan faktor non produk adalah 
reputasi merek, harga, ketersediaan pasokan produk, produk yang mudah didapatkan dan harga jual kembali.

\section{Kerangka Pemikiran}

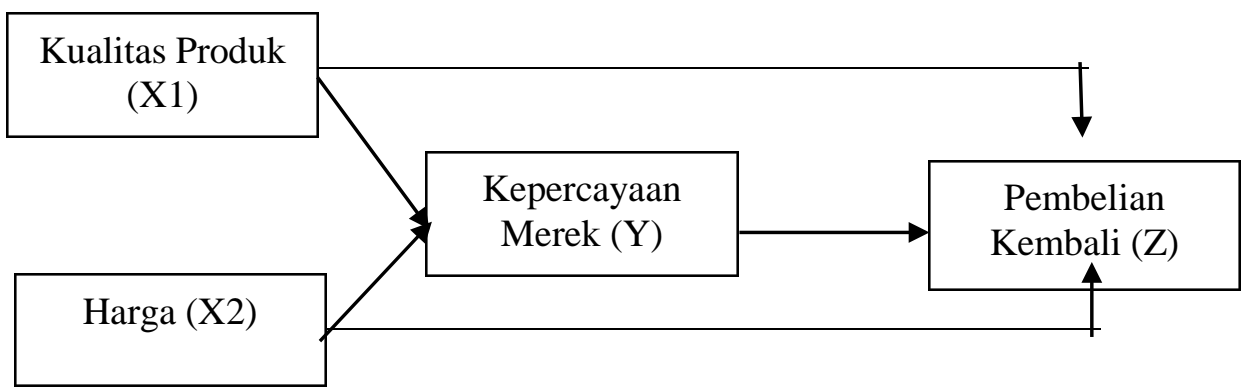

\section{Gambar 1}

\section{Kerangka Pemikiran}

Teori dan kerangka berpikir di atas dapat disusun beberapa hipotesis sebagai berikut:

1. Kualitas produk berpengaruh signifikan terhadap kepercayaan merek GOSH di Kota Palu.

2. Kualitas produk berpengaruh signifikan terhadap pembelian kembali produk GOSH di Kota Palu.

3. Harga berpengaruh signifikan terhadap kepercayaan merek GOSH di Kota Palu.

4. Harga berpengaruh signifikan terhadap pembelian kembali produk GOSH di Kota Palu.

5. Kepercayaan merek berpengaruh signifikan terhadap pembelian kembali produk GOSH di Kota Palu.

\section{METODE PENELITIAN}

Penelitian ini merupakan jenis penelitian kausal dimana ditujukan untuk menganalisis hubungan sebab akibat antar variabel yaitu variabel-variabel kualitas produk dan harga sebagai variabel eksogen, sedangkan variabel kepercayaan merek dan pembelian kembali sebagai variabel endogen. Sebagaimana dikemukakan oleh Sugiyono, (2014a) bahwa penelitian deskriptif adalah metode yang digunakan untuk menganalisa data dengan cara mendeskripsikan atau menggambarkan data yang berlaku untuk umum atau generalisasi. Teknik pengambilan dan pengumpulan data yang dilakukan dengan cara: observasi, wawancara, kuesioner, dan dokumentasi. Populasi dalam penelitian ini adalah para pelanggan yang telah menggunakan produk GOSH di Kota Palu. Teknik pengambilan sampel untuk menentukan sampel yang akan digunakan dalam penelitian ini menggunakan Teknik Purposive sampling. Mengingat jumlah populasi yang tidak diketahui secara pasti, ukuran sampel dalam penelitian ini dilakukan dengan menggunakan pendekatan yang di rujuk dari Sugiyono (2014b) yang menyatakan bahwa untuk menentukan sampel dari populasi yang tidak diketahui adalah minimal 10 kali dari jumlah jumlah variabel yang diteliti (variabel eksogen + variabel endogen). Jumlah variabel dalam penelitian ini adalah 4 yang terdiri atas 2 variabel eksogen yaitu Kualitas Produk dan Harga sedangkan 2 variabel dependen yaitu Kepercayaan Merek dan Pembelian Kembali. Berdasarkan pertimbangan tersebut maka penulis menetapkan jumlah sampel dengan ketentuan 25 x 4 variabel yaitu 100 responden, dengan demikian sampel dari penelitian ini adalah 100 orang. 


\section{Analisis Partial Least Square (PLS)}

Analisis Partial Least Square merupakan salah satu metode yang saat ini digunakan untuk menutup kelemahan yang ada para metode regresi, dengan pendekatan Variance Based SEM atau yang lebih dikenal dengan Partial Least Square (PLS). Untuk melakukan analisa dengan menggunakan PLS software yang sering digunakan adalah smartPLS, warpPLS, dan XLStat. Penelitian ini menggunakan software smartPLS.

\section{HASIL DAN PEMBAHASAN}

\section{Analisis Partial Least Square (PLS)}

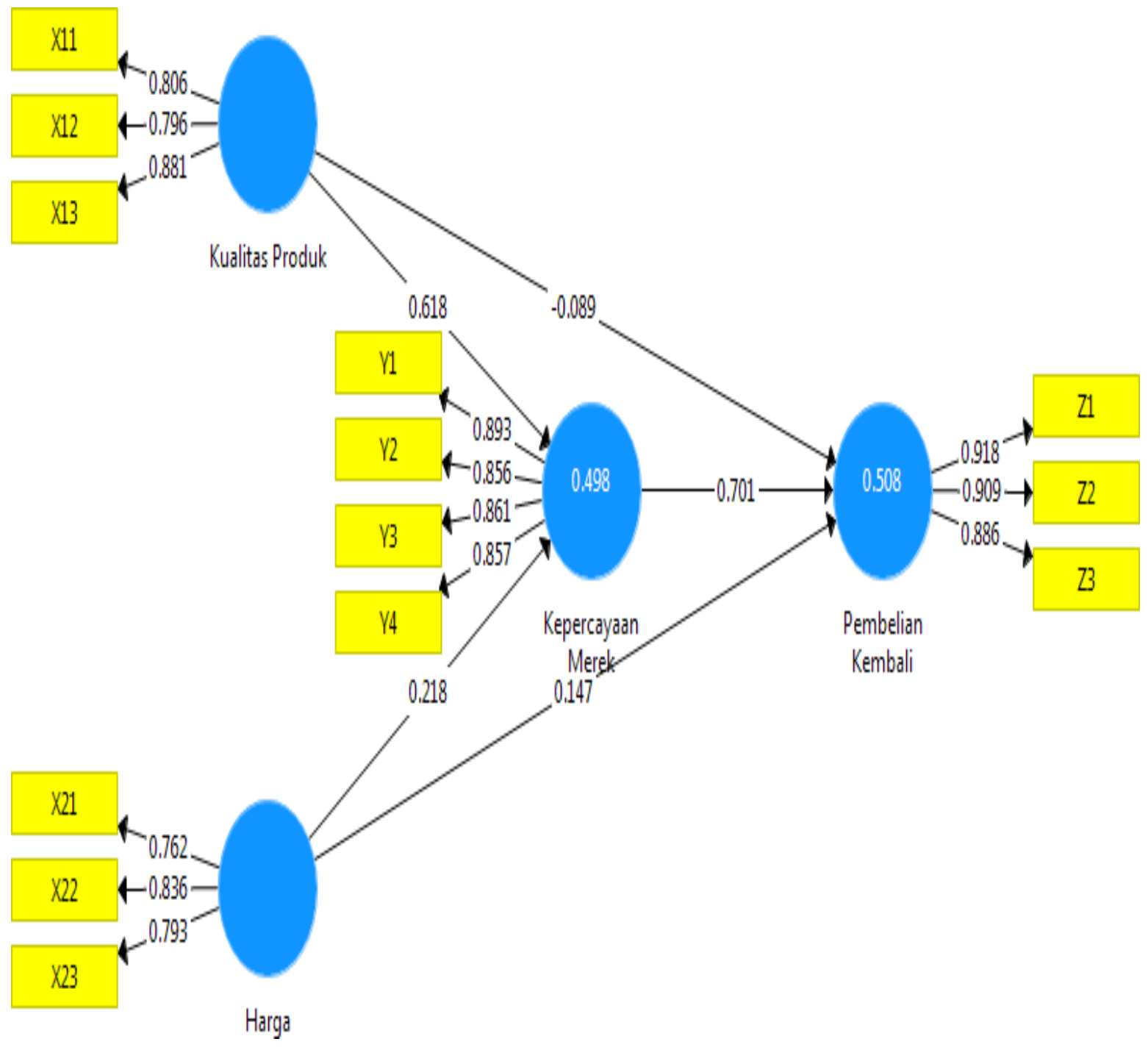

Sumber: Pengolahan data dengan SmartPLS

\section{Gambar 2}

Model Pengukuran (Outer Model) 


\section{Validitas Konvergen}

Tabel 1 Validitas Konvergen

\begin{tabular}{lcc}
\hline \multicolumn{1}{c}{ Variabel } & Indikator & Loading Factor \\
\hline Kualitas Produk & X11 & 0,81 \\
& X12 & 0,80 \\
& X13 & 0,88 \\
\hline Persepsi Harga & X21 & 0,76 \\
& X22 & 0,84 \\
& X23 & 0,79 \\
\hline Kepercayaan Merek & Y1 & 0,89 \\
& Y2 & 0,86 \\
& Y3 & 0,86 \\
& Y4 & 0,86 \\
\hline Pembelian Kembali & Z1 & 0,92 \\
& Z2 & 0,91 \\
& Z3 & 0,89 \\
\hline
\end{tabular}

Sumber: Pengolahan data dengan SmartPLS

Berdasarkan tabel validitas konvergen di atas menunjukkan bahwa semua loading factor memiliki nilai di atas 0,7 ; maka dapat disimpulkan bahwa seluruh indikator memenuhi syarat validitas konvergen.

\section{Validitas Diskriminan}

Validitas diskriminan merupakan nilai cross loading factor yang berguna untuk mengetahui apakah konstruk memiliki diskriminan yang memadai yaitu dengan cara membandingkan nilai loading pada konstruk yang dituju harus lebih besar dibandingkan dengan nilai loading dengan konstruk yang lain.

Evaluasi validitas diskriminan dilakukan dengan menggunakan nilai Average Variance Extracted (AVE). Nilai AVE yang direkomendasikan untuk memenuhi validitas diskriminan adalah AVE $>0,50$.

Tabel 2

Nilai AVE

\begin{tabular}{lc}
\hline \multicolumn{1}{c}{ Variabel } & $\begin{array}{c}\text { AVE (Average Variance } \\
\text { Extracted })\end{array}$ \\
\hline Harga & 0,64 \\
Kepercayaan Merek & 0,75 \\
Kualitas Produk & 0,69 \\
Pembelian Kembali & 0,82 \\
\hline
\end{tabular}

Sumber: Pengolahan data dengan SmartPLS (2018)

Tabel di atas memperlihatkan bahwa nilai AVE untuk semua konstrak di atas adalah sebagai berikut: Harga (0,64), Kepercayaan Merek $(0,75)$, Kualitas Produk $(0,69)$ dan Pembelian Kembali $(0,82)$. Semua nilai AVE dari variabel penelitian ternyata lebih besar dari 0,5 , sehingga dapat disimpulkan bahwa evaluasi pengukuran model memiliki validitas yang baik. 


\section{Composite Reliability dan Cronbach's Alpha}

Composite Reliability dan Cronbach's Alpha digunakan sebagai penguji reliabilitas. Data yang memiliki composite reliability > 0,7 mempunyai reliabilitas yang tinggi, sedangkan untuk Cronbach's alpha nilai yang diharapkan > 0,6 untuk semua konstruk. Berikut adalah hasil dari analisis composite reliability dan Cronbach alpha yang telah dilakukan.

Tabel 3

Nilai Composite Reliability dan Cronbach's Alpha

\begin{tabular}{lcc}
\hline \multicolumn{1}{c}{ Variabel } & Cronbach's Alpha & Composite Reliability \\
\hline Harga & 0,74 & 0,84 \\
Kepercayaan Merek & 0,89 & 0,92 \\
Kualitas Produk & 0,77 & 0,87 \\
Pembelian Kembali & 0,89 & 0,93 \\
\hline
\end{tabular}

Sumber: Pengolahan data dengan SmartPLS

Berdasarkan Tabel di atas dari uji composite reliability, didapatkan hasil bahwa seluruh variabel mendapatkan hasil di atas 0,70. Demikian halnya dengan hasil Cronbach's alpha didapatkan hasil bahwa seluruh variabel memiliki nilai di atas 0,60. Sehingga, dapat disimpulkan bahwa model penelitian ini telah mempunyai reliabilitas yang baik.

Adjusted R-Square $\left(\mathbf{R}^{2}\right)$

Pengujian terhadap model struktural dilakukan dengan melihat nilai R-Square yang merupakan uji goodness-fit model.

\section{Tabel 4}

Nilai R-Square

\begin{tabular}{lcc}
\hline & R-Square & R Square Adjusted \\
\hline Kepercayaan Merek & 0,50 & 0,49 \\
Pembelian Kembali & 0,51 & 0,49 \\
\hline
\end{tabular}

Sumber: Pengolahan data dengan SmartPLS (2018)

Berdasasarkan Tabel diatas kepercayaan merek memiliki nilai R-square sebesar 0,50. Hal ini menjelaskan bahwa pengaruh Kualitas Produk (X1) dan Harga (X2) terhadap kepercayaan merek (Y) sebesar 50\% sedangkan 50\% lainnya dipengaruhi oleh faktor lain. Sedangkan pembelian kembali memiliki nilai R-square sebesar 0,51. Hal ini menjelaskan bahwa pengaruh kualitas produk (X1), harga (X2) dan kepercayaan merek (Y) terhadap Pembelian Kembali (Z) sebesar 51\% sedangkan sisanya 49\% dipengaruhi oleh faktor lain di luar model.

\section{Pengujian hipotesis}

Menguji hipotesis dapat dilihat dari nilai t-statistik dan nilai probabilitas. Untuk pengujian hipotesis menggunakan nilai sruktural maka untuk alpha 5\% nilai t-statistik yang digunakan adalah 1,96. Sehingga kriteria penerimaan/penolakan hipotesis adalah Ha diterima dan $\mathrm{H} 0$ ditolak ketika t-statistik $>1,96$. 


\section{Tabel 5}

Uji Hipotesis

\begin{tabular}{lcccccc}
\hline \multicolumn{1}{c}{ Hipotesis } & $\begin{array}{c}\text { Original } \\
\text { Sample }\end{array}$ & $\begin{array}{c}\text { Sample } \\
\text { Mean }\end{array}$ & $\begin{array}{c}\text { Standard } \\
\text { Deviation }\end{array}$ & $\begin{array}{c}\text { T } \\
\text { Statistics }\end{array}$ & $\begin{array}{c}\text { P } \\
\text { Values }\end{array}$ & Ket \\
\hline $\begin{array}{l}\text { Harga } \rightarrow \\
\text { Kepercayaan }\end{array}$ & 0,22 & 0,23 & 0,08 & 2,66 & 0,01 & Signifikan \\
$\begin{array}{l}\text { Merek } \\
\text { Harga } \rightarrow\end{array}$ & & & & & & Tidak \\
$\begin{array}{l}\text { Pembelian } \\
\text { Kembali }\end{array}$ & 0,15 & 0,15 & 0,08 & 1,74 & 0,08 & Signifikan \\
$\begin{array}{l}\text { Kepercayaan } \\
\text { Merek } \rightarrow\end{array}$ & 0,70 & 0,70 & 0,09 & 7,71 & 0,00 & Signifikan \\
$\begin{array}{l}\text { Pembelian } \\
\text { Kembali }\end{array}$ & & & & & & \\
$\begin{array}{l}\text { Kualitas Produk } \\
\rightarrow \text { Kepercayaan }\end{array}$ & 0,62 & 0,61 & 0,13 & 4,71 & 0,00 & Signifikan \\
$\begin{array}{l}\text { Merek } \\
\text { Kualitas Produk } \\
\rightarrow \text { Pembelian }\end{array}$ & $-0,09$ & $-0,08$ & 0,10 & 0,93 & 0,35 & Signifikan \\
\hline $\begin{array}{l}\text { Kembali } \\
\text { Sumber: Pengolahan data dengan SmartPLS }\end{array}$ & & & &
\end{tabular}

\section{Pembahasan}

1) Hasil perhitungan menunjukkan bahwa pengaruh harga terhadap kepercayaan merek sebesar 0,23 dengan nilai t-statistik 2,66 pada tingkat signifikansi (P-value) 0,01. Berdasarkan nilai signifikansi sebesar 0,01 dimana nilai tersebut lebih kecil dari $\alpha=0,05$; maka dapat disimpulkan bahwa hipotesis 1 yang berbunyi harga berpengaruh signifikan terhadap kepercayaan merek produk GOSH di Kota Palu dinyatakan diterima, dengan demikian dapat disimpulkan bahwa harga berpengaruh positif dan signifikan terhadap kepercayaan merek produk GOSH.

2) Hasil perhitungan menunjukkan bahwa pengaruh harga terhadap pembelian kembali sebesar 0,15 dengan nilai t-statistik 1,74 pada tingkat signifikansi (P-value) 0,08. Berdasarkan nilai signifikansi sebesar 0,08 dimana nilai tersebut lebih besar dari $\alpha=0,05$; maka dapat disimpulkan bahwa hipotesis 2 yang berbunyi harga berpengaruh signifikan terhadap pembelian kembali produk GOSH di Kota Palu dinyatakan ditolak, dengan demikian dapat disimpulkan bahwa harga tidak berpengaruh signifikan terhadap pembelian kembali produk GOSH.

3) Hasil perhitungan menunjukkan bahwa pengaruh kepercayaan merek terhadap pembelian kembali sebesar 0,70 dengan nilai t-statistik 7,71 pada tingkat signifikansi (Pvalue) 0,00 . Berdasarkan nilai signifikansi sebesar 0,00 dimana nilai tersebut lebih kecil dari $\alpha=0,05$; maka dapat disimpulkan bahwa hipotesis 3 yang berbunyi kepercayaan merek berpengaruh signifikan terhadap pembelian kembali produk GOSH di Kota Palu dinyatakan diterima, dengan demikian dapat disimpulkan bahwa kepercayaan merek berpengaruh positif dan signifikan terhadap pembelian kembali produk GOSH.

4) Hasil perhitungan menunjukkan bahwa pengaruh kualitas produk terhadap kepercayaan merek sebesar 0,61 dengan nilai t-statistik 4,71 pada tingkat signifikansi (P-value) 0,00. 
Putri, H.M.

Berdasarkan nilai signifikansi sebesar 0,00 dimana nilai tersebut lebih kecil dari $\alpha=0,05$; maka dapat disimpulkan bahwa hipotesis 4 yang berbunyi kualitas berpengaruh signifikan terhadap kepercayaan merek produk GOSH di Kota Palu dinyatakan diterima, dengan demikian dapat disimpulkan bahwa kualitas produk berpengaruh positif dan signifikan terhadap kepercayaan merek produk GOSH.

5) Hasil perhitungan menunjukkan bahwa pengaruh kualitas produk terhadap pembelian kembali sebesar -0,08 dengan nilai t-statistik 0,93 pada tingkat signifikansi (P-value) 0,35 . Berdasarkan nilai signifikansi sebesar 0,35 dimana nilai tersebut lebih besar dari $\alpha=0,05$; maka dapat disimpulkan bahwa hipotesis 5 yang berbunyi kualitas produk berpengaruh signifikan terhadap pembelian kembali produk GOSH di Kota Palu dinyatakan ditolak, dengan demikian dapat disimpulkan bahwa kualitas produk berpengaruh negatif dan tidak signifikan terhadap pembelian kembali produk $G O S H$.

\section{KESIMPULAN DAN SARAN}

\section{Kesimpulan}

1. Kualitas produk berpengaruh signifikan terhadap kepercayaan merek $G O S H$ di Kota Palu.

2. Kualitas produk tidak berpengaruh secara signifikan terhadap pembelian kembali produk GOSH di Kota Palu.

3. Harga berpengaruh signifikan terhadap kepercayaan merek GOSH di Kota Palu.

4. Harga tidak berpengaruh signifikan terhadap pembelian kembali produk GOSH di Kota Palu.

5. Kepercayaan merek berpengaruh signifikan terhadap pembelian kembali produk $G O S H$ di Kota Palu.

\section{Saran}

1. Bagi perusahaan

a Disarankan pada GOSH di Kota Palu untuk memperkuat kualitas produk dengan cara meningkatkan daya tahan dan kualitas produk yang diciptakan oleh perusahaan. Selain itu untuk meningkatkan kepercayaan merek maka perusahaan harus tetap menawarkan produk-produk berkualitas.

b. GOSH di Kota Palu sebaiknya memperkuat kepercayaan merek dengan selalu menawarkan produk-produk dengan harga yang sepadan dengan kualitas produknya untuk tetap menjaga kepercayaan pelanggan.

2. Bagi peneliti selanjutnya

Bagi peneliti selanjutnya yang ingin meneliti atau melanjutkan penelitian ini, disarankan untuk meneruskan atau mengembangkan penelitian ini dengan mencari faktor lain yang dapat mempengaruhi kepercayaan merek dan pembelian kembali. Perluasan penelitian juga dapat dilakukan dengan meningkatkan jumlah sampel dan penarikan sampel secara probabilitas. 


\section{REFERENSI}

Andre, Y. . (2009). Analisis Hubungan antara Kepuasan Pelanggan dan Loyalitas Pelanggan terhadap Keinginan Pembelian Ulang, Studi Kasus di Universitas bunda Mulia. Business \& Management journal Bunda Mulia, 5(1).

Chinomona, R. (2016). Brand Communication, Brand Image and Brand Trust as Antecedents of Brand Loyalty in Gauteng Province of South Africa. African Journal of Economics and Management Studies, 7(1).

Edris, M. (2013). Hubungan Kepercayaan Merek Terhadap Loyalitas Merek (Studi Kasus pada Detergen Merek Rinso di Kabupaten Kudus).

Geofanny, B., \& Chairy. (2010). Pengaruh Psikologi Konsumen Terhadap Keputusan Pembelian Kembali Smartphone Blackberry. Jurnal Manajemen Teori dan Terapan Tahun 3, (2).

Ghanimata, F., \& Kamal, M. (2012). Analisis Pengaruh Harga, Kualitas Produk, dan Lokasi Terhadap Keputusan Pembelian (Studi pada Pembeli Produk Bandeng Juwana Elrina Semarang). Fakultas Ekonomika dan Bisnis. Diambil dari http://eprints.undip.ac.id/36184/

Kotler, P., \& Amstrong, G. (2001). Prinsip-prinsip Pemasaran. Jakarta: Erlangga.

Kotler, P., \& Amstrong, G. (2012). Principles of Marketing (14 ed.). New Jersey: Pearson.

Kotler, P., \& Keller, K. (2006). Marketing Management (12th ed.). New Jersey: Pearson Education Inc.

Kustini, Nuruni, \& Ika. (2011). Experiental Marketing, Emotional Branding, and Brand Trust and their Effect on Loyalty on Honda Motorcycle Product, 14(1).

Lau, G. ., \& Lee, S. . (1999). Consumer's Trust in a Brand And The Link To Brand Loyalty, 4.

Mc, C., \& Perrefault. (2003). Dasar-Dasar Pemasaran. Jakarta: Erlangga.

Prawira, Bayu, \& Yasa Kerti, N. N. (2014). Pengaruh Kualitas Produk, Citra Merek dan Persepsi Harga terhadap minat Beli Produk Smartphone Merek Blackberry di Kota Semarang, 3(12).

Purwati, Setiawan, H., \& Rohmawati. (2012). Pengaruh Harga dan Kualitas Produk Terhadap Keputusan Pembelian Motor Honda Matic Beat (Studi Kasus Pada PT. Nusantara Solar Sakti, 2(3).

Rendy. (2015). Pengertian Produk, Definisi Kualitas Produk, dan Dimensi Kualitas Produk. Diambil dari https://surabaya.proxsisgroup.com/pengertian-produk-definisi-kualitasproduk-dan-dimensi-kualitas-produk/

Simamora, B. (2003). Membongkar Kotak Hitam Konsumen. Jakarta: PT. Gramedia Pustaka Utama.

Sugiyono. (2014a). Metode Penelitian Manajemen: Pendekatan Kuantitatif, Kualitatif, Kombinasi, Penelitian tindakan dan Penelitian Evaluasi (3rd ed.). Bandung: Alfabeta. 


\section{Putri, H.M.}

Sugiyono. (2014b). Statistika Untuk Penelitian. Bandung: Alfabeta.

Surachman, S. . (2008). Dasar-dasar Manajemen Merek. Bandung: Bayumedia Publising.

Swastha, B. D. (2006). Manajemen Penjualan. Yogyakarta: BPFE.

Tjiptono, F., Chandra, G., \& Adriana, D. (2008). Pemasaran Strategik. Sydney, Kudus dan Jakarta: ANDI Yogyakarta. 